\title{
The Politics of Population Movements in Contemporary Iraq: A Research Agenda
}

\author{
Géraldine Chatelard ${ }^{1}$
}

\begin{abstract}
Chapter in R. Bocco, J. Tejet and P. Sluglett (eds.) (forthcoming) Writing the History of Iraq: Historiographical and Political Challenges, London: World Scientific Publishers/Imperial College Press.
\end{abstract}

\begin{abstract}
This essay, in the form of a research agenda, focuses on the politics of population movements from the inception of the modern Iraqi state to the present. Based mainly on secondary sources, it asks questions, offers hypotheses and opens up a number of conceptual pathways in part drawing from Michel Foucault's notion of governmentality. It is proposed to consider how population movements were affected by the state and other political actors, particularly in the process of nation building and in recent struggles over the control of the state. Within this framework, displacement and policies restricting the mobility of people or forcing their emplacement in certain locations could be read as forms of control political actors have exerted over populations. Other instances of population movements can be interpreted as the uncontrolled results of policies of political or economic engineering, crises of the political system or political decisions leading to armed conflicts. It is suggested that, beyond the numerous and brutal ruptures in Iraqi political history, a study of the politics of population movements throughout the modern history of Iraq identifies some of the continuities that have existed in the exercise of power under successive regimes but also the sociological continuum that exists between states and would-be-states. A further argument is that examining the multiple effects of governmentality on human mobility and immobility in Iraq allows a possible reading of the way in which certain practices of power and certain political identities have been historically encoded leading to patterns of reproduction of violence.
\end{abstract}

\footnotetext{
${ }^{1}$ Associate Researcher at the Institut français du Proche-Orient (Ifpo), Amman. The author would like to thank Hamit Bozarslan, Peter Harling, Riccardo Bocco and Peter Sluglett for their suggestions about previous versions of this chapter.
} 
A significant blind spot in the historiography of contemporary Iraq is the question of the recurrence and durability of population displacement and forced migration. ${ }^{2}$ Whereas a large body of research has been devoted to Palestinian displacement, to the point of constituting an area of scholarship per $s e$ within the broader field of Palestinian studies, displacement and other forms of involuntary migration in and from Iraq have largely escaped academic interest as topics in their own right. Recent trends of involuntary migration taking place in the wake of the change of regime in 2003 particularly the sectarian-based displacement which erupted on a large scale after the al-"Askari shrine bombing in Samarra' in 2006 - have spurred a new policy interest for those Iraqis defined by international law and humanitarian organisations as refugees when they have crossed international boundaries and as internally displaced persons (IDPs) when they have fled from their homes but remained inside their country. As seems to be invariably the case with 'hot' issues on international humanitarian and policy agendas, a growing number of researchers - particularly doctoral students affiliated with Western European and North American universities - are focusing on the post-2003 displacement. ${ }^{3}$ Several publications are already available attempting to provide documentary or analytical views of the most recent trends of internal displacement and refugee migration since the regime of Saddam Hussein was brought to an end. ${ }^{4}$ These works, published or in progress, are dominated by the approach of refugee studies and concerned mostly with the anthropological, sociological, humanitarian or policy dimensions of involuntary migration from Iraq to foreign countries. First-hand empirically based academic research on the dynamics, politics and socioeconomic effects of involuntary migration inside Iraq is conspicuously lacking, possibly because of a tense security situation which is not conducive to research. On the other hand there might also be a more structural reason for this near absence of research on involuntary migration inside Iraq: the tendency of refugee studies to focus on the same issues, populations and geographical areas as those of concern to institutional actors within the international refugee regime whose mandate has traditionally emphasised the protection of refugees in host countries.

The focus on current trends, and on refugee experiences and institutional policies outside Iraq has at least two important disadvantages. On the one hand, it leads to disregarding historical continuities in the phenomenon of involuntary migration in/from Iraq. On the other hand, causality for internal displacement and refugee movements is widely attributed to generalized violence and intersectarian conflict ensuing from the security void created by a weak state after regime change in 2003. In this vision, which appears to be the one most generally shared by humanitarian actors and Western governments with a stake in Iraq, a restoration of state authority - expected to guarantee

\footnotetext{
${ }^{2}$ There is considerable debate in the overlapping fields of forced migration and refugee studies with regard to terminology and typologies. Here, I use displacement when migration takes place under direct compulsion, whereas I reserve forced migration for cases where compulsion exists but is indirect and the scope for deciding to migrate is wider. I use involuntary migration, or involuntary population movements, to encompass both instances. I do not deny that subjects have the capacity to exert their agency and make migration decisions even under severe compulsion, but it is not my aim in this essay to discuss the perspective and experience of the migrants themselves. ${ }^{3}$ Personal observations and communications with over forty, mostly US and Western European, researchers since 2007.

${ }^{4}$ Since 2007, advocacy and humanitarian organisations have produced dozens of reports on Iraqi refugees abroad and IDPs inside Iraq. Media coverage, especially in the US and UK press, has been important as of 2008. A number of documentary films and book essays, mostly by journalists, have also been devoted to Iraqi refugees. A new but growing trend is that of memoirs written by Iraqis who recount their experiences of exile. Published academic or para-academic production is yet limited albeit, here too, growing (see, in particular, Marfleet 2007; Shoeb et al 2007; International Crisis Group 2008; Leenders 2008; Sassoon 2008; Doraï 2009; Chatelard 2010).
} 
overall security and re-start economic development ${ }^{5}$ - is seen as the solution which will curb new involuntary migration and lay the ground for the return of the refugees and those internally displaced. For those acquainted with the modern history of Iraq, maybe the most problematic aspect of this faith in the role of the state to solve the current 'Iraq displacement crisis' and prevent new involuntary population movements is that is it precisely the Iraqi state, in its various guises between 1920 and 2003, that has been the main entity responsible for involuntary migration inside and outside the country. Furthermore the Iraqi state, especially under Saddam Hussein, also displayed remarkable tenacity at retaining many Iraqis inside the country against their will, ${ }^{6}$ and at confining certain populations to specific areas of Iraq. Without seeming excessively pessimistic about the type of regime that will emerge from a consolidation of the new Iraqi state, it is worthwhile reflecting upon the fact that government stability and economic prosperity in Iraq - both of which existed to some extent, however briefly, under the rule of the $\mathrm{Ba}$ 'th - have not previously been synonymous with the principle of freedom of movement. Although I will not address the issue here, I would argue that it is useful to consider recent trends of displacement and forced migration in the light of previous episodes and ask in precisely which ways the post-Saddam Hussein trends differ from previous ones while still displaying several similar characteristics.

No general historical work on modern Iraq fails to mention the episodes of mass displacement or forced migration to which Assyrians, Kurds of all persuasions, Turkmen, Jews, individuals deemed of Iranian descent, and Shi' $i$ Arabs from the South have been subjected. In the same books, readers will find accounts of the emigration (by eviction or voluntary exile) of political opponents or irredentist populations, such as the Kurds and Yazidis, a trend that dates back to the British mandate era (1920-32). Most of the instances of displacement, forced and political migration listed above have also been documented, often in great detail and using original sources, in scholarly monographs devoted to particular ethnicities, displacement episodes, political parties or historical periods. Iraqi historians writing from the perspective of Arab nationalism or official Ba 'thist history are no more prone than their colleagues with different outlooks to gloss over involuntary migration and political emigration. They simply place them in a different interpretive framework and couch them in other terms.

In addition to scholarly works, involuntary migration features largely in the apologetic writings dealing with, and often produced by politicized intellectuals among, Iraqi Shi' is, Kurds, Turkmen and Assyrians, and in the advocacy literature of human rights and refugee organisations. It would be surprising if published or unpublished memoirs, essays and pamphlets by members of opposition parties in Iraq overlooked these issue. Here too the selection of facts, interpretation and terminology are likely to differ from the ones adopted by historians trained in Western academia. Most certainly, such accounts must stand in sharp ideological contrast to those written by pan-Arab or Ba'thist historians.

${ }^{5}$ Economic factors have been identified by Philip Marfleet (2007) as one major cause of departure from Iraq in the post-2003 period.

${ }^{6}$ Alan Dowty, who surveyed emigration policies worldwide in the 1980s, placed Iraq on a list of 21 states imposing severe restrictions on the ability of their citizens to leave the country of their own free will. The most obvious common denominator among these states was not the level of economic development, nor the threat of brain drain, but the nature of the regime: all were heavily ideologized one-party states. Iraq stood out, together with Burma and Somalia, as an exception in that, contrary to the 18 other states, it was not a self-defined Marxist-Leninist regime. Dowty notes that: "Although large numbers [of people] may occasionally leave such states, legal exit is basically viewed as a privilege to be granted by the government rather than a right to be exercised" (1988: 90). 
What seems to be lacking, therefore, is not historical and empirical material - necessarily varied in nature and perspective - but rather any conceptual attempt to link various types and episodes of involuntary migration together to try to make sense of the recurrence of the phenomenon and of a certain regularity in patterns. This is what I propose to attempt in this essay by broadening the perspective to discuss the politics of population movements from the inception of the modern Iraqi state to the present. In addition to what is classically subsumed under the phrase involuntary migration, this problematization will lead me to consider other types of population movements affected by the state and other political actors.

\section{Nation building and state control over population movements}

State and conflict-induced population displacements and migration have a long history in the Middle East, going back to the Ottoman empire and beyond to the Byzantine era. Such population movements also have a broad regional scope and their effects are felt in most of the modern states previously under Ottoman rule (Shami 1996). In the introduction to her recent historical and ethnographic study, Displacement and Dispossession in the Modern Middle East, Dawn Chatty notes that "The Middle East in particular has been the scene of continuous forced migration over the past 150 years" and that dispossession of people in the region should be located "as part of the policy of empire, carried further by the colonial encounter and then revitalized in the Arab socialist awakening of the mid-twentieth century" (2010: 1-2).

There are several possible frameworks through which to interpret the complexity and durability of involuntary population movements in Iraq. However the overarching one is likely to remain the process of nation building. Modern Iraq indeed appears as a classical case of twentieth century postimperial nation-state formation of the type that the prominent refugee studies scholar Aristide Zolberg analysed in his seminal 1983 article on "The Formation of New States as a RefugeeGenerating Process." Population displacements in Iraq were intrinsically linked to the creation of a nation state seeking to homogenize populations, assert sovereignty over territories contested by other nationalist claims, silence domestic political opposition, and perform population engineering as part of policies of modernisation and development. Successive Iraqi regimes have exerted control over population movements both by limiting the mobility of certain categories of the population inside the national territory and across borders, and by forcibly displacing other categories internally or outside the national space under a variety of policies and legitimization regimes. While displacement took place under direct compulsion exerted by state authorities or because of conflict, forced migration for its part was usually the uncontrolled results of policies of political engineering or modernisation, particularly the mass migration from rural to urban areas. Other trends of emigration under various levels of constraint were the consequences of crises of the political system or political decisions taken by governments. This was the case with the departure of families who were members of the elite under the monarchy after the 1958 revolution. It was also the case with the economic migration of the middle class under the international embargo imposed on Iraq in 1991 as a result of the invasion of Kuwait, and, arguably, with the exodus of the Christians over the same period. Each of these emigrant groups were driven by a set of dynamics that cannot be reduced to their relations with the state, but in each instance, state policies were a determining factor that indirectly impacted their decision to leave Iraq.

Recasting displacement as a form of state control over populations entails considering the phenomenon in correlation with policies restricting the mobility of people or forcing their emplacement and confinement in certain locations. Through systems of identification that formed the basis for exclusion and inclusion practices successive political powers have defined the boundaries of the nation and created different categories of subjects. These categories ranged from those fully admitted into the national body to those alien to it and susceptible to be physically 
expelled from the country. Several groups fell into intermediate categories: they were the primary targets of population engineering by the state, particularly mass relocation from one area to another inside the country or forced confinement. Some also ran the risk of being downgraded to non nationals. ${ }^{7}$ Furthermore, other types of manifestations of authoritarian governance have to be considered as regards the effects of state policies over human mobility, particular forms of exclusion from the allocation of economic resources under developmental regimes.

At another level, and more obliquely, practices of control over population movements represent an angle from which to understand the durability of violence as a means of exercising and accessing power. Examining the multiple effects of governmentality on human mobility and immobility allows a possible and more inclusive reading of the way in which certain practices of power and certain political identities have been historically encoded leading to patterns of reproduction of violence. ${ }^{8}$ Looking at the nexus between state policies and population movements/mobility has the potential to illuminate a series of extremely important historical phenomena in contemporary Iraq. On the one hand, it may help understand how, in the construction process of a post-imperial, postcolonial, self-declared progressive and developmentalist nation-state - where the public discourse of nationalism and modernisation has generally dominated - a set of social, religious and cultural identities have continued to be primordialized and have acquired (or have not lost) political and conflictual dimensions. Furthermore, looking at the movements of population throughout the modern history of Iraq identifies some of the continuities that have existed in the exercise of power under successive regimes - monarchical, republican, military -, all autocratic or authoritarian in varying degrees. Finally, an examination of control over population movements across time might reveal the sociological continuum that exists between states and would-be-states, that is the actors who project themselves from exile or from inside Iraq as potential states. Population movements should therefore be read as a factor structuring political identities and the reproduction of political violence.

One important premise guides my argument: the rejection of essentializing analyses of violence and political instability in Iraq as being intrinsically embedded in the fragmentary nature of the society based on supposedly incompatible religious, ethnic or tribal identities. These approaches are problematic from an epistemological as well as a moral point of view. Morally, they justify authoritarianism and state coercion' ${ }^{9}$ as necessary modes of governance to 'hold together' groups between which no social contract is alleged to be possible. Alternatively, they have come to inspire

${ }^{7}$ By degrees, such sanctification of national identity and exclusionary policies laid the ground for justifying, during the last phases of the Anfal campaign, the mass physical elimination of those rural Kurds who resisted relocation from their villages in areas where Kurdish guerilla were active (the so-called "prohibited areas"), and who did not register in the 1987 national census as residents of designated towns or residential complexes under government control. These Kurds lost their Iraqi citizenship and were presented by the official rhetoric not only as traitors and saboteurs, but also as having excluded themselves voluntary from the national ranks. Families of "unrepentant saboteurs" were physically removed from government-controlled areas and forced to join their kin in the prohibited areas. This mass deprivation of citizenship seems to have been a necessary step in convincing local commanders loyal to the central Iraqi regime to enforce a directive ordering armed forces to kill all living beings, human or animal, within the prohibited areas (see Human Rights Watch 1993: Chapter 2).

${ }^{8}$ I draw theoretically on the concept of governmentality developed by the philosopher Michel Foucault and on the work of political scientist John Torpey on the monopoly claimed by modern states on the legitimate means of circulation (Torpey 1988; Caplan and Torpey 2001).

${ }^{9}$ I take coercion as a category of political violence exerted on populations by states or other political organisations (parties, militias, etc.). 
the political project of territorial-based ethnic and confessional federalism promoted and implemented in post-Ba'thist Iraq at various times both by the US Administration and by a number of local political actors. Epistemologically, I share the hypothesis put forth by several scholars of Iraq that political identities based on 'primordial' affiliations are largely historical constructs. ${ }^{10}$ They have developed in a dialectical relation between state powers (colonial rulers, Iraqi national governments, or governments of neighbouring countries) and local leaderships: the latter have been cast by state rhetoric and actions as ethnic or religious leaders; at other times, ethnic or religious identity politics has proven more efficient to access resources and power. Note should also be taken of the works of scholars who have shown that this dynamic has coexisted with the development of other non-sectarian and non-ethnic political ideologies, from pan-Arabist and communist to Iraqi nationalism. ${ }^{11}$ Others have underlined one particularly striking feature of modern Iraq: the coexistence, within the authoritarian state, of modernisation policies expressed through development projects and the allocation of resources. ${ }^{12}$ What follows should be taken as a thesis in progress and a research agenda that offers hypotheses and tries to open up a number of conceptual pathways in the hope that some will be tested and others contested by scholars of contemporary Iraq.

\section{Control over mobility and political coercion}

Although the volume of the various displacement episodes taking place in Iraq since the 1920s has been variable, one constant has been their collective nature: the displaced have been members of social groups identified by various political regimes as sharing an identity both cohesive and primordialized (ethnic, confessional, ethno-confessional or ethno-national, but also based on kinship ties within a patriarchal system) deemed incompatible with and/or a threat to some notion of an Iraqi national order. Several episodes have been massive, with people displaced by the tens and even hundreds of thousands. Others affected only members of the religious or political elites of specific groups. Displacement was induced directly by state policies of deportation usually following denial of citizenship or denationalization. This was the case as early as 1923, with a handful of prominent Shi' $i$ clerics who were also political leaders opposed to the British mandate whose Iraqi nationality was contested or in some cases taken away by the government before they were deported to Iran (Nakash 1994; Luizard 1996). In the early years of the Ba'thist takeover, this line of thinking re-emerged with great vigour: the same accusations of collusion with Iran and betrayal of Iraqi national interests were made against Shi 'is deemed of Iranian descent who were deported in very large numbers in the 1970s and 1980s (Nakash 1994; Babakhan 1994a). Through a series of discriminatory measures, executions, and accusations of Zionism, almost all the Jewish population of Iraq was convinced to relinquish their Iraqi citizenship and emigrate between 1950 and the early 1970s (Shiblak 1986). In all instances, it was in the name of the defence of Arab nationalism that vast groups of the population were denied national status and consequently expelled from the Iraqi national body.

Armed conflicts, domestic or international, have also provided direct or indirect inducements for forced population movements, especially those that erupted in connection with the Kurdish and Assyrian nationalist claims as early as the 1930s. Kurdish displacement continued for decades, peaking in the 1980s during the eight-year war with Iran. Revolts against the Ba'thist regime, particularly the 1991 uprising in the South and North of the country, were other occasions for large scale displacement inside Iraq or to neighbouring countries (Yacoub 1986; Babakhan 1994a; Babakhan 1994b; Fuccaro 1997; Alborzi 2006). Whereas some populations were forced out of

${ }^{10}$ In particular, see Peter Harling's contribution to this volume.

${ }^{11}$ Especially Hanna Batatu (1978), Sami Zubaida (2003), and Eric Davis (2005).

${ }^{12}$ Such as, but not limited to, Marion Farouk-Sluglett and Peter Sluglett (1983), and Habib Ishow (1996). 
specific spaces (rural, regional or national), the Ba'thist regime in parallel pursued policies of population redistribution and demographic engineering combining the relocation of some ethnic groups (particularly the Kurds and the Turkmen) and importing Arabs, the policy of the so-called Arabisation of the oil-producing regions of Kirkuk and Mosul (Hilterman 2007). Most of these displacements were linked to one another: the settlement of Arabs lead to displacement of Kurds and Turkmen through different administrative techniques entitling the former to food distribution, land and house ownership while depriving the others of those same entitlements (Romano 2005).

In contrast with liberal states, successive Iraqi regime have not enshrined in law the principle of the free circulation of their nationals. The granting of travel documents has been restricted from the time of the British mandate until the post-Ba'thist era under various types of legitimation and using various administrative practices. Under the $\mathrm{Ba}^{\text {'th }}$, passports were delivered on the basis of individual and family loyalty or at least individual compliance with the regime, while the post-2003 government introduced new control mechanisms on issuing passports shortly after it came to power. ${ }^{13}$ In both cases, national security has been used as the principal justification for checking the political loyalties of those allowed mobility across borders. More recently, a new mechanism has been put in place to control the exit of nationals by proxy. At the request of the Iraqi government, Syria and Jordan, whose regulations had previously permitted the free entry of Iraqis, introduced visas in 2007. Those wanting to leave Iraq now have to undergo a double process of screening by the Iraqi authorities and those of Syria or Jordan (Chatelard and Doraï, forthcoming). This is not to say that Iraqis have not been able to by-pass the various control mechanisms imposed on their movements, in particular by resorting to irregular practices (bribes, forged documents, etc.) or by activating patronage ties. However this has financial and social costs which in themselves act as selection mechanisms on would-be migrants including those fleeing violence (Chatelard 2010).

Other types of mass population movements have been approached from the perspective of control over land ownership and production and the enhanced socio-economic role of the landlords. Alternatively, they have been analyzed from the perspective of social, economic and political history. They can also be read more systematically as displacement phenomena resulting, often unintentionally, from the application of authoritarian policies in the rural areas. In successive historical periods, land or agricultural policies in rural Iraq have been motivated by a national political agenda. This was the case when the monarchy sought to reinforce the economic base and the allegiance to the regime of a Kurdish and Arab landowning elite (Farouk-Sluglett and Sluglett 1983). After the 1958 military coup, the state's new agrarian policies were aimed at undermining the power of this elite and ensuring state control over land (Ishow 1996). Although policies shifted radically between the monarchy and the various post-1958 regimes, the various land-tenure or agrarian reforms correlated directly with the massive migration (within the range of several millions) of peasants to urban centres, particularly Baghdad and Basra, between the late 1920s and the 1970s. This large scale internal migration had long-term repercussions on the economic and socio-political fabric of the country. The concept of "development-induced displacement" could be adequate if it did not generally fail to qualify the context within which development decisions are taken, which generally served to conceal the inequalities of power and coercion mechanisms in society.

Highly authoritarian measures to maintain the rural labour-force in the countryside had largely proved counter-productive. Under the monarchy, to contain the massive potential migration of impoverished peasants to the cities, a legislation was passed in 1933 (the Law Governing the Rights and Duties of Cultivators) about which Marion Farouk-Sluglett and Peter Sluglett wrote: "One of

\footnotetext{
${ }^{13}$ Author's interviews with Iraqi migrants and refugees having left Iraq during the embargo and after the 2003 change of regime.
} 
the most important features of the law was that fallahin indebted to the landowner were not permitted to leave his employment until the debts were paid off. As the vast majority were permanently indebted, the only way to break the circle was to run away from the land" (FaroukSluglett and Sluglett 1983: 500). After 1958, the republican and military regimes applied policies of nationalisation of arable lands within a socialist ideological frame prioritising state planning and the collectivisation of the means of production, and later, at the time of the Iran-Iraq war, the privatisation of these state-owned lands to wealthy individuals (Ishow 1996: 195). All these measures failed to increase agricultural production substantially or to keep peasants in the countryside. The latter move, in correlation with the drafting of Iraqi men to be sent to the Iranian front, created the conditions for another massive population movement, the migration to Iraq of almost half a million Egyptian agricultural labourers (Ishow 1996: 194)

Habib Ishow identifies the principle of state property over lands as bearing heavily upon the rural communities by legitimizing de jure and de facto abuse of authority on the part of central governments (Ishow 1996: 192). In addition to the poor performances of the agricultural sector and food insecurity, it resulted in destructuring rural communities and the tribal system. In the cities it brought about new class distinctions and new dynamics of economic, social and spatial marginalisation and eventually mobilisation and violent claims against the regime. The term shruqi became a stigmatizing social category originally used by Baghdadi urbanites to qualify the new migrants of rural background settled in slums on the periphery of the city, especially the area that became integrated into the urban fabric as a poor city neighbourhood, called Madinat al-Thawra in 1958 and as Madinat as-Sadr after the fall of the Ba'th. At this juncture, the term came to be used in a derogatory manner by those castigating poor militant Shi' is. The further swelling of impoverished marginal neighbourhoods in the cities of the south and centre in the 1990s resulted also in part from state policies depriving non-compliant social groups of access to vital resources. The draining of the marshes in the early 1990s led to the destruction of the habitat and livelihoods of a marginal rural Shi' $i$ population that was evading the control of the regime. The number of shruqi-s kept growing in the cities and at least in the imagination of those who have been casting them as barbarian Others, now form the majority of the recruits of the Jaysh al-Mahdi militia, one of the would-be-state organisations that carried out new forms of violence and sectarian cleansing in several major urban centres between 2006 and 2008.

In combination with control over the international movement of nationals, various legal or administrative measures have aimed at confining populations to specific spaces inside Iraq. This was the case with the settlement policies of tribespeople on agricultural estates owned by landlords and control of the cross-border movement of bedouin tribes aiming at settling populations, containing them within national boundaries and making them obedient and productive subjects (Toth 2006: 70). Already under the monarchy civil status registration in one's place of residence was used as a means of population control and to coerce peasants to remain as debt-bonded labourers on the estates of landowners (Ishow 1996: 118). Here again, fugitives to the cities tried to escape coercion by avoiding registration. The system remained in place throughout subsequent decades until the food distribution system which was introduced during the Iran-Iraq war, and which was maintained in place during the economic embargo starting in 1991, became a more effective tool of population surveillance and control since ration cards had to be renewed annually and change of residence without re-registration would entail the loss of entitlements (Von Sponeck 2006: 35). The vast number of fugitives and displaced during the last period of $\mathrm{Ba}$ 'thist rule were de facto deprived of access to important food resources. In other instance, the confiscation of ration cards was used by the government's coercive apparatus to force people to move. The ration card system, which has remained in place under the post-Ba'thist regime, continues to be used by various authorities as a means to induce people either to move or to remain where they are. More 
than in the past, the cards have become a tool of population engineering, ensuring the ethnic, sectarian or tribal homogeneity of entire areas, and the forming of electoral constituencies now that the same system serves as the basis for voter registrations. The situation of those displaced in the previous period or under the new regime, the so-called IDPs, is critical in this regard (Romano 2005: 438). Today, a number of other administrative measures imposed by the central government as well as by the Kurdish Regional Government (KRG) impede mobility between areas inside the country: in addition to rations cards that cannot be easily transferred between administrative areas, non-Kurdish Iraqis residing in the centre or south of the country who want to enter the Kurdish autonomous region are compelled to find a legal guarantor who is a civil servant in the administration of the KRG.

The modalities of repression via state or other control over the mobility of political opponents have been different and devised in relation to the way regimes have qualified the nature of oppositions, rather than in relation to the way these oppositions have expressed and identified themselves. On the one hand, the various regimes have constantly tried to "purify" Iraq from those recalcitrant social elements whose ethnic or confessional identities could be amalgamated with non-Iraqi or non-Arab identities (such as Assyrian, Jews, Iranian, Kurds or Turkmen). However, even between categories of non-Arabs, the political grammar of Arabism in Iraq has operated a distinction between the Jew/Zionist, and Kurdish or Persian/Iranian. Since the creation of the state of Israel, the former has implied an absolute disqualification and separation from Arabism, whereas the latter two have allow certain patterns of inclusion or a least relations. On the other hand, regimes have tried to discipline and punish within the national space oppositions expressed in the idioms of nationalist or internationalist political ideologies (Communism, pan-Arabism, Syrian Ba'thist in particular) not totally incompatible with the versions of Arabism sponsored by Iraqi governments.

Political repression was translated into various modes of control over mobility, from expulsion and deportation to confinement - including house arrest and incarceration. In all cases, however, this control represented one particular form of coercion accompanied by other forms of violence, including the physical elimination of individuals as members of social groups redefined as political groups. All possible manner of violence was applied, ranging from torture and individual executions, to collective assassinations and mass killings. In several instances, mass crimes, in particular against the Kurds (Babakhan 1994b; Hilterman 2007), also caused large-scale displacement inside or outside the country. In other instances, the deliberate deprivation of access to resources vital for the security of individuals (land, water, food, shelter, access to employment in the public sector, citizenship) compelled large numbers of the categories targeted to migrate to other areas where alternative resources or security were available. Finally, individuals have sought to protect themselves from coercion by withdrawing within infra-state social units (whether religious community, tribe, family, domestic space), not necessarily implying physical but social, symbolic and psychological displacement (Bozarslan 2003: 32).

Under all the different political regimes in Iraq, and in various ways, the state has placed entire categories of the population in situations of great insecurity through actions in different spheres (legal, administrative, economic, political, security, military etc.) but whose commonality is that they were expressions of a sovereignty that did not seek legitimation through the rule of law, universal suffrage or the people's exercise of democratic choice. For the individuals or the groups targeted by coercion, spatial mobility has represented an answer, reactive or planned, to recover security, inviting in turn new responses from the state in its aim to maintain control over individuals and populations.

A vast research agenda remains to be open that would allow the identification of the trajectories of 
the changes - emergence, amplifications or decline - in coercion practices and methods. A major question is the recurrence of several of these practices under different political regimes, a phenomenon that calls for interrogating how various security agencies have endowed coercive practices with different meanings and have embedded them in difference systems of legitimation. New ideological frames of reference, new emergencies, new historical contingencies have all provided new interpretive frameworks and vocabularies justifying coercion and control of mobility, and new types of social groups upon whom to apply this control. The content and meaning of such notions as treason and enmity in particular have shifted over time. This leads to questioning the production of discourse and symbols by state authorities, along the lines of Eric Davis' work (2005) on historical memory and authoritarian rule under the $\mathrm{Ba}^{6}$ th. While expanding an examination of official narratives and representations to the monarchy, republican and post-Ba'thist periods, there should be a particular focus on the elaboration and dissemination of discourses justifying control over population movements: imaginations of the nation and of the threats allegedly bearing down upon it, territorial borders and internal social and spatial boundaries, security and protection, enmity and treason, and images and sources of inspiration regarding sovereignty and its performance are all themes that should be traced, unpacked and studied in connection with the power practices they justified.

Other items on a research agenda would be the structures put in place for the identification and categorisation of individuals that are a pre-requisite to control their mobility. Here again, time frames should be delineated and their coinciding with ruptures in political history should be verified. The example of the food distribution system that has been carried over from the Ba'thist to the post-Ba'thist era is a case in point. Another one is the mention of religious or tribal affiliation on identity cards: in which contexts were various items and categories introduced or removed? Still another one is the presence or absence in censuses of questions on ethno-national affiliation, particularly Turkish (for the Turkmen) or Kurdish and the implications for individuals of registering as such ${ }^{14}$. One objective would be to identify spheres of action (legal or administrative), methods or techniques (such as censuses), and technologies (such as statistics or computerisation) that have been used by successive regimes and non-state political actors today to objectify individuals through practices of identification and identity categories, in particular as members of a biological group (the patriarchal family, the tribe) or of a community (an ethnicity, a religious group, a national body).

A rich area of research concerns the actors who imagined and developed the categories of identification together with policies and measures of confinement, exclusion or expulsion. What are their backgrounds? What were their models, their inspirations at difference periods? How was the Indian colonial model adapted to the Iraqi theatre by the mandate administration and how was it contested or implemented by high-level civil servants under the monarchy? Similar questions could be asked about the adoption of a Stalinist model by Saddam Hussein, and an Israeli model for the US occupying power. What models do today's militias use to categorise individuals and to operate ethnic or sectarian cleansing? What about the KRG? An as a corollary, how have individuals strived to evade the stigmas attached to certain identifications and resulting threats on their security? Identity concealment, formal religious conversion (empirical evidence suggests that both were adopted by a number of Iraqi Jews in order to remain in Iraq), the recourse to patronage in rural and urban contexts, attempts to secure alternative identity documents by bribing civil servant or

\footnotetext{
${ }^{14}$ It is unclear from the literature when and in which regions certain categories were used, and also if published census results reflected the questions asked when censuses were taken. For Kurds in the 1987 census, see Human Rights Watch (1993) and also Michiel Leezenberg (1997) for the case of the Shabak, a small syncretistic religious communities in northern Iraq, who were displaced as a result of their registering as Kurds.
} 
acquiring them on the false identity market, as well as migration itself have all been strategies to evade the ascriptive dimension of identity categorisation and its effects.

\section{Political migration and the reversal of violence}

Especially since the 1958 revolution that overthrew the monarchy, a considerable number of Iraqis have attempted to escape direct political repression or limitations on their individual freedom by leaving the country. This politically motivated emigration, in conjunction with successive waves of displacement resulting from violence and conflict, has led to the formation of exile communities of Iraqis in several Middle Eastern countries (Iran, Saudi Arabia and the Gulf, Jordan, Syria, Yemen and, to a lesser extent, Turkey) and beyond (Great Britain and a number of other Western European states, countries of the former Eastern bloc, the USA, Canada, Australia etc.) (Cigerli 1998; AlRasheed 1998; Vanly 2002; Fattah 2007; Shoeb et al 2007; Chatelard 2010). At times, these 'exits' from the national and political space have taken place despite measures put in place by the state security apparatus to control the movements of opponents beyond national boundaries. At other times, they have been the result of deportations carried out by state authorities.

From a historical perspective, spatial mobility cannot be considered anomalous in the Middle East (Shami 1996; Chatty 2010). In the Iraqi context in particular, the Ottoman legacy calls for a reexamination in relation to more recent trends of emigration. Modern Iraqi society inherited from the Ottoman era vast and complex social networks based on the free circulation of people, goods, money, and ideas and extending far beyond what became the frontier of the modern state. Pastoral herders, tribal leaders, traders, Shi'i pilgrims, religious students or clerics, members of Sunni Sufi orders, Kurdish nationalist elites, members of extended families and of certain ethnic or ethnoreligious communities (Assyrians and Chaldeans, Turkmen etc.), those influenced by Turkish and Iranian intellectual movements, activists in modern political parties (like the Syrian Ba 'th) etc. have all circulated within and exchanged across ecological, social, religious, political and economic spaces whose boundaries have never coincided with those of states. People of all social classes and ethnicities have therefore been mobile and, for those who were not, their social world was shaped and influenced by the mobility of others who belonged to their tribal, familial, intellectual, political or religious group. Territoriality and identity as defined by the practices and subjectivities of these social groups have differed markedly from those defined by the national order that colonial and post-colonial states have striven to create and secure. Places of deportation or emigration outside Iraq can therefore at times be conceptualised as spaces of belonging and familiarity rather than spaces of exile and alienation, especially if they provide security and access to material, social and/ or symbolic resources.

As for political migration, its 'identity cycle' in space and time and within changing political and ideological contexts should be considered to understand how particular identities, claimed or ascribed in Iraq, have been maintained or reshaped in migration and mobilized to contest regimes in power in Iraq and, eventually, to take power through violence. How has the context of the countries of emigration provided the resources to claim political power in Iraq? In which rhetoric have these claims been voiced: as victims, minorities, as pan-Arabists, pan-Turkists, as Assyrian or Kurdish nationalists, as communists, internationalists, revolutionaries, in the vocabulary of political Islam, in sectarian terms etc.? What types of mobilisations have been available (armed, militant, diplomatic, intellectual etc.)? A particularly important question to be asked is why, unlike the nationalist momentum of the 1970s-early 1990s within the Palestinian refugee diaspora which was similarly scattered between several countries and split into numerous political currents, Iraqi political exiles and refugees did not develop a unified discourse and practices of resistance. What have been therefore the historical factors and local dynamics that have maintained the fragmentation of the discourse, of the actions and of the identities of Iraqi exiles? 
Together with the above, another set of questions regards the production of antagonistic group memories as victims and of competing visions of an Iraqi political project. What are the experiences and idealised frames of reference that have come to shape the collective imaginations of the exiles? How have those who have escaped violence through emigration integrated into their subjectivities and projects the experiences of those members of their groups who have suffered torture, assassination, displacement etc.? What role do the ideas of return and revenge play in these imaginations and projects?

When the international balance of power allowed political groups from the diaspora to participate on the Iraqi national stage in 2003, violence was first turned against the individuals who had contributed to the maintenance of the Ba'thist regime. Eventually violence was also aimed at a whole series of social groups, negating their right of existence in a unified political community on the basis of their 'difference'. The theme of 'insiders' $v s$. 'outsiders', of exile and return, initially restructured the political arena and that of violence. However, the process of 'othering' shifted quickly to take on sectarian overtones. The groups and factions competing for power in the new Iraqi political order took over the monopoly of the exercise of violence (Al-Rachid and Méténier 2007: 115) and also appropriated another former monopoly of the $\mathrm{Ba}$ 'thist state: the means and modalities of control over population movements. In the last few years, a multiplicity of collective actors has directed violence against the confessional, ethnic and class composition of entire urban and rural areas, displacing populations inside and outside the country, and forcing others to be immobilised. Many members of the Ba'thist political, military and bureaucratic elite have been compelled to emigrate, mostly to other Arab countries, from where some have attempted to mobilise resources to support the resistance undertaken by neo-Ba'thist insurgents inside Iraq. Violence and vexations exerted against secular intellectuals and members of certain professional groups, and against women who refuse to conform to norms of public behaviour deemed Islamic have all been incitements to remain within restricted domestic or social spaces or, conversely, to leave Iraq for neighbouring countries or the West, or to take refuge in the 'pacified' Kurdish autonomous region. Iraq is today characterised by an uneven socio-spatial distribution of human security: human mobility is restricted due to the fragmentation of the Iraqi national space into subunits under different kinds of sovereignty, and to the insecurity attached to the expression or presumption of certain group identities in specific areas. On the one hand, the sorting out of populations on ethnic, communal and class grounds is outliving the rule of the militias and other armed groups who initiated the process. Relative social homogeneity is now maintained through other economic and psychological mechanisms (such as livelihoods found in new areas of residence, the fear of moving back to former neighbourhoods, internalization of the ethno-sectarian territorial divide etc.) and, arguably, due to government policies to maintain displaced populations in the areas where they have been displaced. On the other hand, the Iraqi government and the occupation forces have developed measures to contain population movements between neighbourhoods and regions (security barriers and walls, check-points, registration systems etc.) while exit from central and southern Iraq towards the Kurdish north or neighbouring countries is impeded in various ways both by the Iraqi authorities and by those of neighbouring political entities. This is despite the fact that the uneven socio-spatial distribution of security inside Iraq still makes mobility, for many individual and collectives, a strategy of security.

One possible reading of the reluctance of Premier Nuri al-Maliki and most members of his government - the majority of whom lived in exile in Iran, Syria and elsewhere, some of them since the 1970 s - to take any meaningful step towards engaging with those who have taken refuge abroad since 2003 is their belief that forced exile is a deserved punishment or, alternatively, that refugees 
are traitors who refuse to adhere to the political project of the so-called new Iraq ${ }^{15}$. In this conceptualization, those newly exiled are paying the price for having caused - if only by having failed to be sufficiently active in their opposition to Saddam Hussein - the exile of those who are in power today. Similar remarks can be made regarding practices on the ground and official policies aimed at reversing the demographic balance that resulted from the Arabization campaign in the areas disputed between the KRG and the Baghdad government. For the political leadership, in Baghdad as well as in the KRG, "a displacement for a displacement" is therefore a just retribution in a vision of justice where the punishment of perpetrators must equate the wrong they have committed, but also where whole social groups can be made responsible for the doings of one or some of their members. Whatever the cultural (some would say tribal and Islamic) legitimation of this juridical ethos, it is a matter of particular concern that the new Iraqi authorities, far from trying to playing a mediating role by sponsoring processes of reconciliation between different groups and generations of exiled and internally displaced persons, are partisan actors justifying, if not actively promoting, revenge through involuntary migration. Let us note here that although the Iraqi state today is no longer the proximate cause of forced migration, there is a remarkable continuity in the conception of retributive justice and the moral economy of displacement shared by the ruling elites.

Many of those working in humanitarian organizations wonder about the possible return of recent exiles said to belong in their vast majority to the educated and secular middle class. Others have discussed $^{16}$ the effects of the most recent brain drain that entails loss of competence and human capital but also jeopardizes the bases on which a pluralistic civil society might be constructed in the new Iraq. Might the current ruling powers be convinced by these arguments and finally pursue a pro-active policy to regain the confidence of the exiles and promote their return? Or rather, might we see a repetition of the period between the 1950s and the 1980s when the economic void created by the involuntary emigration of Jews, Fa'ili Kurds and other Shi' is - who also formed a large part of the economic, professional and intellectual elite - was rapidly filled by an emerging middle class trained and employed in government institutions and who became the new clients of the state? Several testimonies from recent exiles who have tried to regain their positions as civil servants point to the fact that posts have been filled by a new generation of graduates whose allegiance to one or the other faction in the new government is ensured, and who are overwhelmingly Shi' is, many from lower middle class backgrounds. ${ }^{17}$ The vast program of 10,000 scholarships launched by Premier alMaliki to support the education of postgraduates in all disciplines in the best foreign universities is also already starting to produce a new cohort that is taking over from those who have fled the country. The socio-economic background, sectarian affiliation and political leaning of the majority of the grantees is anyone's guess.

In this context, despite the radical rupture in the Iraqi political order as of 2003, continuities with previous periods need to be highlighted. This item on a research agenda centred on the nexus between violence, human mobility and identity politics will require in depth exploration of the actors who have redistributed between themselves the means of control over population movements, their modalities of action, and the effects of the latter on individual experiences of violence and collective identities. In post-Ba 'thist Iraq such notions as territoriality and sovereignty have been profoundly altered. The state lost, and is trying to regain, the monopoly over coercive violence and over its technologies. It also lost the monopoly over the symbolic resources needed to exert and legitimise this violence. How the relations between violence and population movements are being reconfigured today is a crucial question.

\footnotetext{
${ }^{15}$ Several public statements by members of the Maliki government support this analysis.
}

${ }^{16}$ See Joseph Sassoon's contribution to this volume.

${ }^{17}$ Author's interviews with Iraqis in Amman and Damascus in 2009-10. 
What therefore could be read through a systematic study of the politics of population movements is that, beyond the numerous and brutal ruptures in Iraqi political history, governmentality in modern Iraq can be analysed along the paradigms of the developmental and the authoritarian state. Both are models adopted concomitantly by ruling powers to exert their sovereignty over populations by sorting individuals out along naturalized identity categories, each the object of different treatment. In modern Iraq, it is the state (and would-be.states) which appears as the principal instrument of the fragmentation of the social and the political by categorising people not as individual citizens but as members of quasi-biologized collectives. The result is that Iraqis today do not see themselves as citizens, but as members of particular social groups which have been victimized by one or several other groups. Many, including those at the highest levels of the political apparatus, are locked in mindsets and imaginations that make them incapable of reverting patterns of social fragmentation and political violence of which displacement and forced migration are only some of the consequences.

\section{References}

Alborzi, M. R. (2006) Evaluating the Effectiveness of International Refugee Law: The Protection of Iraqi Refugees, Leiden: Martinus Nijhoff Publishers.

Al-Rasheed, M. (1998) Iraqi Assyrian Christians in London: The Construction of Ethnicity. Lewiston, N.Y: The Edwin Mellen Press.

Al-Rachid, L. and E. Méténier (2007) "À propos de la violence irakienne. Quelques éléments de réflexion sur un lieu commun," A contrario, 2(5): 114-33.

Babakhan, A. (1994a) L'Irak, 1970-94, déportation des chiites, Paris: A. Babakhan. (1994b) Les Kurdes d'Irak. Leur histoire et leur déportation par le régime de Saddam Hussein, Paris: A. Babakhan.

Batatu, H. (1978) The Old Social Classes and the Revolutionary Movements of Iraq: A Study of Iraq's Old Landed and Commercial Classes and of its Communists, Ba 'thists, and Free Officers, Princeton: Princeton University Press.

Bozarslan, H. (2003) "Pouvoir et violence dans l'Irak de Saddam Hussein," in H. Dawod and H. Bozarslan (eds) La société irakienne. Communautés, pouvoirs et violence, Paris: Karthala.

Caplan, J. and Torpey, J. (eds.) (2001) Documenting Individual Identity: The Development of State Practices in the Modern World, Princeton, N. J.: Princeton University Press.

Chatelard, G. (2010) "What visibility conceals. Re-embedding refugee migration from Iraq." in D. Chatty and B. Finlayson (eds) Dispossession and Displacement: Forced Migration in the Middle East and North Africa, New York: Oxford University Press.

Chatelard, G. and Doraï, M.K. (forthcoming) "Les Irakiens en Jordanie et en Syrie: régime d'entrée et de séjour et effets sur les configurations migratoires," in Ch. Lequesnes (ed.) L'Enjeu mondial. Spécial frontiers, Paris: CERI-Sciences Po.

Chatty, D. (2010) Displacement and Dispossession in the Modern Middle East, New York: Cambridge University Press.

Cigerli, S. (1998) Les réfugiés kurdes d'Irak en Turquie, Paris: L'Harmattan.

Davis, E. (2005) Memories of State. Politics, History, and Collective Identity in Modern Iraq, Berkeley, Los Angeles, London: University of California Press.

Dowty, Alan (1988) "The Assault on Freedom of Emigration," World Affairs, 151(2): 85-92.

Fattah, H. (2007) "Les autres Irakiens: émigrés et exilés d'avant 2003 en Jordanie et leurs récits d'appartenance," Revue des mondes musulmans et de la Méditerranée, 117-18: 127-36.

Farouk-Sluglett, M. and Sluglett, P. (1983) "The Transformation of Land Tenure and Rural Social Structure in Central and Southern Iraq, c. 1870-1958," International Journal of Middle East Studies, 15(4): 491-505.

Fuccaro, N. (1997) "Ethnicity, State Formation, and Conscription in Postcolonial Iraq: The Case of 
the Yazidi Kurds of Jabal Sinjar," International Journal of Middle East Studies, 29(4): 55980 .

Hilterman, J. (2007) A Poisonous Affair: America, Iraq and the Gassing of Halabja, Cambridge: Cambridge University Press.

Human Rights Watch (1993) Genocide in Iraq: The Anfal Campaign Against the Kurds, New York: Human Rights Watch.

International Crisis Group (2008) Failed responsibility: Iraqi refugees in Syria, Jordan and Lebanon, Middle East Report, 77, 10 July 2008.

Ishow, H. (1996) L'Irak. Paysanneries, politiques agraires et industrielles au XXe siècle. Contribution à la réflexion sur le développement, Paris: Publisud.

Leenders, R. (2008) "Iraqi Refugees in Syria: causing a spillover of the Iraqi conflict?," Third World Quarterly, 29(8):1563-84.

Leezenberg, M. (1997) "Between Assimilation and Deportation: The Shabak and the Kakais in Northern Iraq," in K. Kehl-Bodrogi, B. Kellner-Heinkele and A. Otter-Beaujean (eds.) Syncretistic Religious Communities in the Near East, Leiden: Brill

Luizard, P.-J. (1996) "Iraniens d'Irak, une élite religieuse chiite face à un état Sunnite," Cemoti, 22: 163-90.

Marfleet, P. (2007) “Iraq's Refugees: 'Exit' from the State," International Journal of Contemporary Iraqi Studies, 1(3): 397-419.

Romano, D. (2005) "Whose House is this Anyway? IDP and Refugee Return in Post-Saddam Iraq," Journal of Refugee Studies, 18(4): 430-53.

Sassoon, J. (2008) The Iraqi Refugees: The New Crisis in the Middle East, London: I. B. Tauris.

Shami, S. (1996) "Transnationalism and Refugee Studies: Rethinking Forced Migration and Identity in the Middle East," Journal of Refugee Studies, 9(1): 3-26.

Shiblak, A. (1986) The Lure of Zion: The Case of the Iraqi Jews, London: Saqi Books.

Shoeb, M., Weinstein, H., and Halpern, J. (2007) "Living in Religious Time and Space: Iraqi Refugees in Dearborn, Michigan," Journal of Refugee Studies, 20(3): 441-60.

Torpey, J. (1988) "Coming and Going: On the State Monopolization of the Legitimate 'Means of Movement'," Sociological Theory, 16(3): 239-59.

Toth, A. B. (2006) "Last Battles of the Bedouin and the Rise of the Modern State in Northern Arabia: 1850-1950," in D. Chatty, (ed.) Nomadic societies in the Middle East and North Africa: entering the 21st century, Leiden: Brill.

Vanly, I.S. (2002) "The Forgotten Feili Kurds of Iraq," in M. Ahmed and M. Gunter (eds) Kurdish Exodus: From Internal Displacement to Diaspora, Sharon, Mass: Ahmed Foundation for Kurdish Studies.

Von Sponeck, H.C. (2006) A different kind of war: the UN sanctions regime in Iraq, Oxford: Berghahn Books.

Yacoub, J. (1986) The Assyrian Question, Chicago: Alpha Graphic.

Zolberg, A. (1983) "The Formation of New States as a Refugee-Generating Process," Annals of the American Academy of Social and Political Science, 467: 24-38.

Zubaida, S. (2003) "Grandeur et décadence de la société civile irakienne," in H. Dawod and H. Bozarslan (eds) La société irakienne: communautés, pouvoirs et violence, Paris: Karthala.

Electronic references

Dorai, M.K. (2009) "L'exil irakien à Damas Modes d'insertion urbaine et reconfiguration des réseaux migratoires," EchoGéo, 8. Online. Available HTTP:

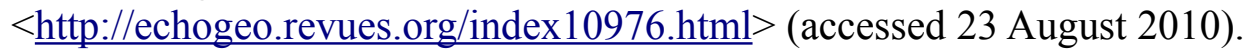

